$\mathbb{T}$ periodica polytechnica

\author{
Transportation Engineering \\ $38 / 2(2010) 73,77$ \\ doi: 10.3311/pp.tr.2010-2.03 \\ web: http://www.pp.bme.hu/tr \\ (c) Periodica Polytechnica 2010
}

RESEARCH ARTICLE

\section{Social benefit estimation of travel time shortage of air transport in Europe}

\author{
Botond Kővári / Ádám Török
}

Received 2009-10-07

\begin{abstract}
The desire for flying has inspired humanity for a long time. It was the Greek Ikaros from legendary, whose principal dream was to fly together with the birds. His attempts were hopeless from the beginning. The aim of our article is to investigate the positive effects of air passenger transportation moreover the mathematical modelling and presentation of the travel time shortening. Europe is modelled by travel time instead of travel distance between the airports, this way Europe's map is transformed significantly.
\end{abstract}

\section{Keywords}

air passenger transport $\cdot$ travel time shortening $\cdot$ revenue

\section{Acknowledgement}

This work is connected to the scientific program of the "Development of quality-oriented and harmonized $R+D+I$ strategy and functional model at BME" project. This project is supported by the New Hungary Development Plan (Project ID: TÁMOP4.2.1/B-09/1/KMR-2010-0002).

\section{Botond Kövári}

Department of Transport Economics, BME, H-1111 Budapest Bertalan L. u. 2., Hungary

e-mail: bkovari@kgazd.bme.hu

\section{Ádám Török}

Department of Transport Economics, BME, H-1111 Budapest Bertalan L. u. 2., Hungary

e-mail: atorok@kgazd.bme.hu

\section{Introduction}

Aviation had been traditionally a strictly regulated industry, dominated by national flag carriers and state-owned airports. The global deregulation and liberalization of air transport which began in the USA at the end of the 1970's - resulted in numerous changes, including the evolution of price-competition, emerging of low-cost airlines, growth in load factor, airport capacity problems, etc. Later, the internal market has eliminated all commercial restrictions for airlines flying within the European Union (EU). Constraints on routes, number of flights, tariff policies, etc. have been removed. EU airlines were permitted to provide air services on any route within the EU. As a result, prices have fallen dramatically, especially on the most popular routes. European aviation now operates with over 130 scheduled airlines, a network of over 450 airports, and 60 air navigation service providers. The aviation sector employs more than 3 million people in the European Union. Airlines and airports contribute more than 120 billion EUR to the European Gross Domestic Product. According to European figures, the airports in Europe have spent 7.5 billion EUR annually on capital expenditure over the last five years. As for the future, there are plans to spend 8.1 billion EUR annually between 2006 and 2010 and 8.5 billion EUR annually between 2011 and 2015, resulting an $8 \%$ and $13 \%$ increase respectively. Figures published by the International Air Transport Association (IATA) on the 27th of March 2009 show that its 230 member airlines reported an overall decline of $10.1 \%$ in international revenue passenger kilometers (RPKs) during February. This was intensified by the extra day last February which means the adjusted decrease is around $6.5 \%$. This is worse than the $5.6 \%$ fall reported in January. For the second month running, only the Middle East managed to report a growth in international RPKs. However, the small RPK growth of $0.4 \%$ was rather undermined by a $7.3 \%$ increase in ASKs resulting an almost 5\% decline in load factor. The Far East market for premium traffic was down $21.2 \%$ in January. Although the recessive economic situation has impacted this industry as well, air transportation is globally very important and influential, imposing great benefits on society. 


\section{Negative effects of air transport}

Air transport and airports perform many important functions in modern societies. Unfortunately, alongside all the positive effects of this critical industry, there are negative aspects too that must also be regarded. As the volume of air transport operations increases and our consciousness of its effects deepen, the impacts of aviation upon the human and natural environment become more and more significant. Analysis of these effects requires international cooperation.

Generally, sustainable development of a given transport system in the long-term could be achieved if its overall positive contribution to the economic and social welfare continuously increases and in the meantime the total negative impact on people's health and the environment decreases. The negative effects imposed by air transportation include the environmental disturbances caused by the airplanes during the process of transporting, as well as while other related functions of the airport are taking place. The detrimental effects occur both in the air and on the ground, this way it is important to evaluate them in both relations. Negative effects are caused by

- The aircraft - taxiing, idling, accelerating, taking-off, climbing, crousing, approaching, landing, decelerating and parking.

- The processes of ground handling - during draining, unloading, cleaning, fuelling, refilling, loading (catering, cargo), towing, start-up assistance and deicing.

- Airport operations - energy supply, heating and waste disposal.

- Passengers - who contribute with their wastes and trash.

- Cargo processes - packaging material.

- Confiscated goods.

- Pesticides.

- The maintenance and repair of the airplanes, other vehicles and machines - during inspection and analysis, cleaning, making adjustments, changing parts and oil, charging and applying lubrication.

The perception of trends in environmental problems is often multifaceted because although many of the adverse effects of air transport - especially noise around airports - have been reduced, people's expectations have risen. Partly, this is caused - beside environmental awareness - by rising living standards and consequently higher expectations. On the other hand, experiencing today's higher stress factors due to struggles in providing, maintaining and improving the standards of life cause intolerance and impatience to these other matters. This is clearly a case where the perceived noise is a function of the subject's relation to the noise source [2].

\section{Positive effects of air transport}

Aviation has become one of the fastest growing sectors of the world economy [3]. Since 1960, air passenger traffic (expressed as revenue passenger-kilometres) has grown at nearly $9 \%$ per year, 2.4 times more than the global average Gross Domestic Product growth rate [4]. There are now over 18,000 commercial aircraft in service, operated by 1300 airlines [5], [6], from approximately 1200 airports producing over three billion passenger kilometres per year. Current global passenger transport by air is approximately 50 times greater than it was 50 years ago [7]. Notwithstanding periodic shocks and the ongoing restructuring of the industry, the demand for fast and reliable air transport is likely to continue under prevailing market conditions. The rate of growth of global passenger traffic slowed to about $5 \%$ in 1997, as the industry matured in some parts of the world [8]. This rate is predicted to continue for at least the next 10 to 15 years [9]. The transportation and within this the air transport has a positive effect on the national economic processes, the consumption and the consumers' circle increases, the mobility is growing and overall due to this the standard of living is increasing, The infrastructure investments of air transport may appear as a positive effect, since new businesses will run and the value of the real estates which can be found there may be growing. The air transport has numberless industrial and commercial relations, this way contributes to the GDP. The air transport reduces the travel time significantly [10]. The aim of our article is to create a "travel time map" for Europe and to estimate the revenue of faster transportation. A time map has been built, which is unusually display not the geographical distance between cities, but the travel time.

\section{Mathematical model of travel time}

Tab. 1. Traffic data of investigated airports [11]

\begin{tabular}{llcc}
\hline City & Airport & Passenger & Rank \\
\hline Amsterdam & Schiphol & 47429741 & 5. \\
Berlin & Tegel & 13357741 & 30. \\
Brussels & Brussels International & 17838214 & 23. \\
Budapest & Ferihegy & 8581071 & 48. \\
Frankfurt & Frankfurt/Main & 54161856 & 3. \\
London & Heathrow & 67056228 & 1. \\
Madrid & Barajas International & 50823105 & 4. \\
Munich & Francz Joseph Strauss & 34530593 & 7. \\
Paris & Charles de Gaulle & 60851998 & 2. \\
Stockholm & Arlanda & 17968023 & 22. \\
Vienna & Schwehat & 18768468 & 20. \\
Zurich & Kloten & 20682094 & 18. \\
\hline
\end{tabular}

Table 1 shows, that the yearly traffic carried by the airports of the investigated European cities are globally, internationally considerable. Because of the specialities of the air transport the foreward and backward travel distance and travel time between two cities may differ from each other. The error deriving from the difference is not significant; due to this the average travel 
distance and time has been used. The average length of the flight route has been used instead of the geographical distance.

The origin-destination travel time and distance were used for visualization of shortening of travel time of air passenger transport (Table 2). The travel time presents the user centred system efficiency [12]. In mathematics and computer science, graph theory is the study of graphs, mathematical structures used to model pair wise relations between objects from a certain collection. A "graph" in this context refers to a collection of vertices and a collection of edges that connect pairs of vertices. In our case we have the vertices as airports and the edges as routes between them. A graph may be undirected, meaning that there is no distinction between the two vertices associated with each edge, or its edges may be directed from one vertex to another.

In the Euclidean space, the distance between two points is given by the Euclidean distance (2-norm distance). For point $\mathrm{A}$ $\left(a_{1}, a_{2},\right)$ and point $B\left(b_{1}, b_{2},\right)$, the distance between $A$ and $B$ is defined as (1):

$$
d_{A B}=\sqrt{\left(\sum_{i=1}^{n}\left|a_{i}-b_{i}\right|^{2}\right)}
$$

In "Cartesian" geometry in 2 dimensions, the minimum distance between two points is the length of the line segment between them (2):

$$
d_{A B}=\sqrt{\left(a_{1}-b_{1}\right)^{2}+\left(a_{2}-b_{2}\right)^{2}}
$$

Where:

$\mathrm{a}_{j}$ : the coordinates of starting point of measurement

$\mathrm{b}_{i}$ : the coordinates of ending point measurement

This give us the shortest straight distance between the two airports. We had to face the fact that the 2-norm "Cartesian" distance is not describing correctly the situation, because the airplane cannot move on the "shortest" path. That is the reason why we have changed the "Cartesian" distance to "travel" distance. "Travel" distance describes the distance between airport $i$ and $j$, by the route between them. In our article we did not take into account the taking off and the landing time. The travel time can act as distance in a mathematical sense, and a symmetric "travel" time distance matrice between $m$ ports can be developed (3):

$$
\mathbf{D}=\begin{array}{lll}
0 & d_{1 B} & d_{1 m} \\
d_{A 1} & 0 & d_{A m} \\
d_{m 1} & d_{m B} & 0
\end{array}
$$

Where:

D is the overall distance matrix (symmetric, square matrix)

$\mathrm{d}_{A B} \quad$ is the travel time distance between port $\mathrm{A}$ and $\mathrm{B}$.

This matrix is a symmetric one, because $\mathrm{d}_{A B}=\mathrm{d}_{B A}$ and if $\mathrm{A}=\mathrm{B}$ then $\mathrm{d}_{A B}=0$. To build up a graph from distances we calculated the relative coordinates of the airports. We used multidimensional scaling (MDS) which is a set of related statistical techniques often used in data visualization. MDS is a special case of ordination. An MDS algorithm starts with a matrix (matrix of distances in this case), and then assigns a "location" of each vertice in a low-dimensional space, suitable for graphing. Relation (3) describes the matrix of Euclidean distances, matrix $\mathbf{D}$, based on the relative coordinates of ports (vertices) in the graph. This is the method how the computer calculates the place of vertices or airports compared to other vertices or airports. As we used an MDS algorithm and the "travel time" distance between the airports, instead of the Euclidean ones, we had to compare the observed "travel time" distances with the calculated data from the MDS, in order to make sure our above model is valid. Measuring the "goodness-of-fit" was therefore necessary. The most common measure that is used to evaluate how well (or poorly) a particular configuration reproduces the observed data (in this case the distance matrix) is the so called "stress measure". The raw "stress value" $\varphi$ of a configuration is defined by:

$$
\varphi=\sum_{i=1}^{m}\left[d_{A B}-f\left(\delta_{A B}\right)\right]^{2}
$$

Where:

$$
\begin{array}{ll}
\mathrm{d}_{A B}: & \text { stands for the reproduced distances } \\
\delta_{A B}: & \text { the input data (i.e., observed distances) } \\
\mathrm{f}\left(\delta_{A B}\right): & \text { indicates a non-metric, monotone transfor- } \\
& \text { mation of the observed input data (distances) }
\end{array}
$$

Thus, the smaller the stress value, the better is the fit of the reproduced distance matrix to the observed distance matrix (in our case the value of $\phi_{\text {air }}$ was 0.22 ). As an alternative way of checking we also produced a Shepard diagram (Fig. 1), i.e. a plot between the reproduced distances plotted on the vertical (Y) axis versus the original distances (maritime) plotted on the horizontal $(\mathrm{X})$ axis (hence, the generally negative slope).

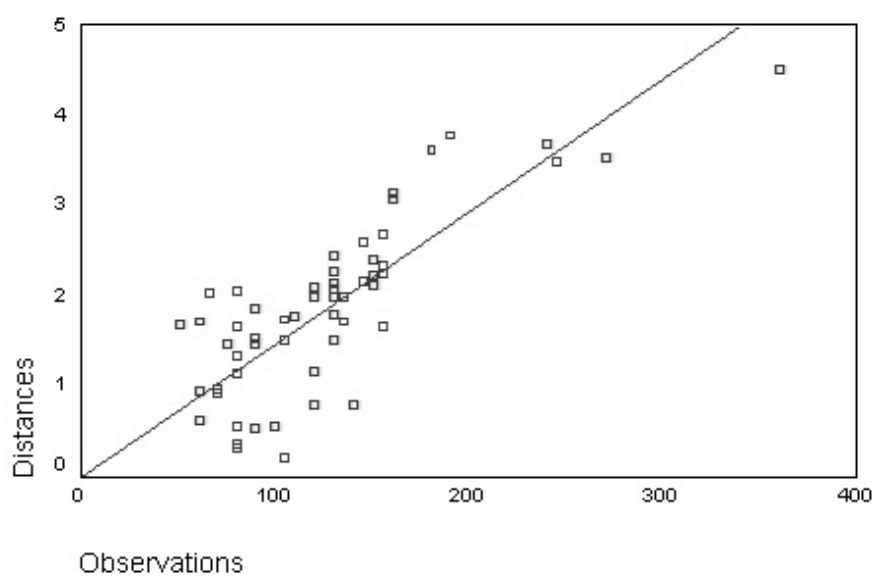

Fig. 1. Shepard diagramm $\left(R^{2}=0.7658\right)$

The correlation coefficient $\left(\mathrm{R}^{2}\right)$, sometimes also called the cross-correlation coefficient, is a quantity that in this case gives the quality of a calculated data (squares on Fig. 1) compared to the ideal (linear on Fig. 1,. $\mathrm{R}^{2}$ is between 0 and 1 , in our case the higher the $\mathrm{R}^{2}$ is the better the transformation was. As it can be seen from Fig. 1 the transformation of distances into a graph 
Tab. 2. Distance and travel time between investigated European cities (source: own research)

\begin{tabular}{|c|c|c|c|c|c|c|c|c|c|c|c|c|}
\hline $\begin{array}{l}\text { Distance }[\mathrm{km}] \backslash \\
\text { Travel time }[\mathrm{h}: \mathrm{mm}]\end{array}$ & $\begin{array}{l}\overline{0} \\
0 \\
\frac{0}{\pi} \\
\frac{\pi}{0} \\
0\end{array}$ & $\begin{array}{l}\tau \\
\text { 음 } \\
0\end{array}$ & $\frac{\mathscr{\infty}}{\frac{\pi}{\pi}}$ & 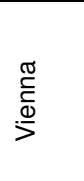 & 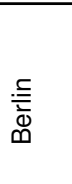 & $\begin{array}{l}\frac{\infty}{0} \\
\infty \\
0 \\
\frac{1}{2}\end{array}$ & $\begin{array}{l}\frac{E}{\pi} \\
\frac{\pi}{0} \\
\frac{0}{0} \\
\frac{0}{\omega 0} \\
\frac{1}{<}\end{array}$ & $\begin{array}{l}\text { 은 } \\
\text { ㅁ } \\
\text { I }\end{array}$ & $\begin{array}{l}\frac{E}{0} \\
\frac{\bar{v}}{0} \\
\text { के }\end{array}$ & 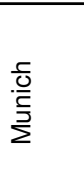 & $\begin{array}{l}\frac{\mathrm{O}}{\mathrm{O}} \\
\frac{3}{N}\end{array}$ & 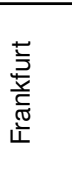 \\
\hline Budapest & & 1500 & 1300 & 250 & 700 & 1200 & 1200 & 2000 & 1400 & 600 & 800 & 850 \\
\hline London & $2: 30$ & 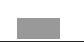 & 350 & 1300 & 950 & 350 & 400 & 1300 & 1450 & 950 & 800 & 650 \\
\hline Paris & $2: 15$ & $2: 20$ & $\square$ & 1050 & 900 & 300 & 450 & 1100 & 1550 & 700 & 500 & 450 \\
\hline Vienna & $1: 00$ & $2: 30$ & $2: 10$ & 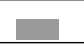 & 550 & 950 & 950 & 1850 & 1250 & 400 & 600 & 650 \\
\hline Berlin & $1: 45$ & $2: 00$ & $1: 45$ & $1: 20$ & 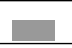 & 700 & 600 & 1900 & 800 & 500 & 700 & 450 \\
\hline Brussels & $2: 00$ & $1: 15$ & $1: 00$ & $1: 50$ & $1: 20$ & 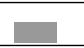 & 200 & 1350 & 1300 & 600 & 500 & 300 \\
\hline Amsterdam & $2: 00$ & $1: 20$ & $1: 20$ & $4: 05$ & $2: 10$ & $0: 50$ & 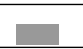 & 1500 & 1150 & 700 & 650 & 400 \\
\hline Madrid & $3: 10$ & $2: 30$ & $2: 10$ & $6: 00^{*}$ & 3:00 & $2: 40$ & $2: 25^{\star}$ & 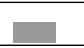 & 2600 & 1500 & 1250 & 1450 \\
\hline Stockholm & $2: 10$ & $2: 40$ & $2: 35$ & $4: 30^{*}$ & $1: 30$ & $2: 15$ & $2: 10$ & 4:00 & 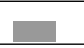 & 1350 & 1500 & 1250 \\
\hline Munich & $1: 20$ & $2: 00$ & $1: 40$ & $1: 05$ & $1: 10$ & $1: 20$ & $1: 30$ & $2: 35$ & $2: 10$ & + & 250 & 300 \\
\hline Zurich & $1: 45$ & $1: 30$ & $1: 20$ & $2: 35$ & $1: 30$ & $1: 10$ & $2: 35$ & $2: 10$ & $2: 25$ & $1: 00$ & 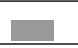 & 300 \\
\hline Frankfurt & $1: 45$ & $1: 40$ & $1: 15$ & $1: 35$ & $1: 10$ & $1: 00$ & $1: 40$ & $2: 40$ & $2: 10$ & $1: 10$ & $1: 15$ & $\square$ \\
\hline
\end{tabular}

has a very low errot 1 . So the new "relative" position of the airports under consideration as based on "travel time" distances and the graph theory representation is different than the known geographic one and this is shown in Fig. 2 .

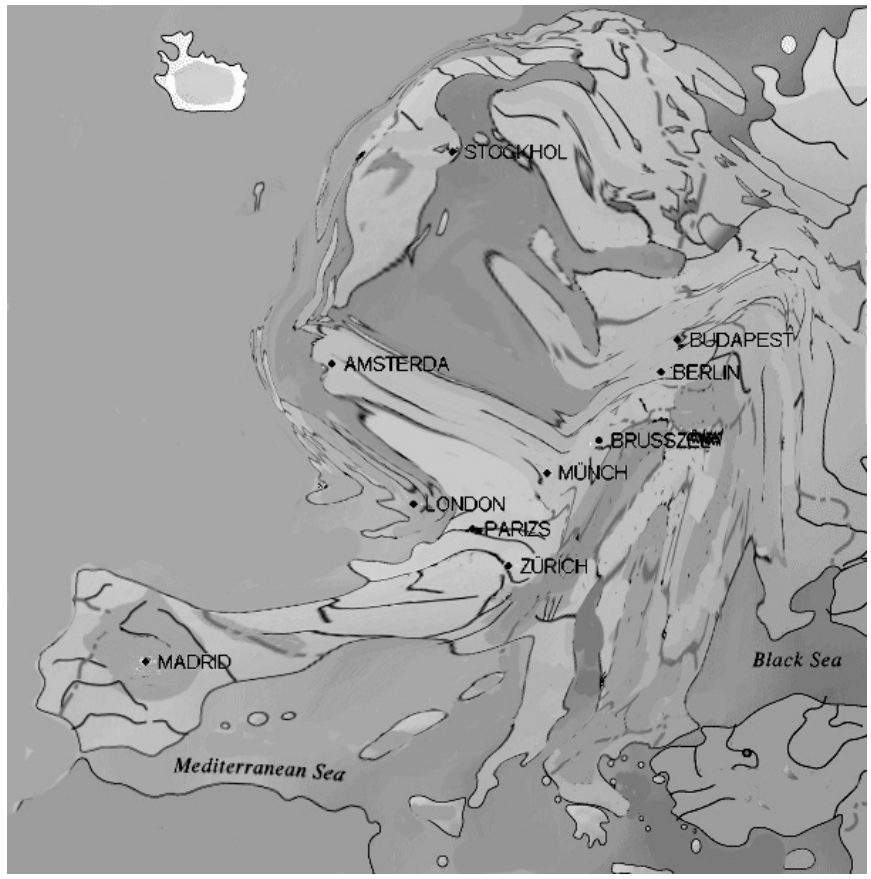

Fig. 2. Map of Europe modified by travel time (source: own research)

\section{Estimated Revenue of travel time shortening}

The Value of Travel Time (VTT) refers to the cost of time spent on transport. The Value of Travel Time Savings (VTTS)

\footnotetext{
1 This line represents the so- called $D$-hat values, that is, the result of the monotone transformation $\mathrm{f}\left(\delta_{i j}\right)$ of the input data. If all reproduced distances fall onto the step-line, then the rank-ordering of distances (or similarities) would be perfectly reproduced by the respective solution (dimensional model). Deviations from the step-line indicate lack of fit.
}

refers to the benefits from reduced travel time. In our article we tried to estimate the revenue of travel time saving of air transportation compared to road transportation (5).

$$
\mathbf{T T S}=\begin{array}{ccc}
T T R_{11}-T T A_{11} & T T R_{1 j}-T T A_{1 j} & T T R_{1 n}-T T A_{1 n} \\
T T R_{i 1}-T T A_{i 1} & T T R_{i j}-T T A_{i j} & T T R_{i n}-T T A_{i n} \\
T T R_{n 1}-T T A_{n 1} & T T R_{n j}-T T A_{n j} & T T R_{n n}-T T A_{n n}
\end{array}
$$

where,

TTS: $\quad$ Travel Time Saving [hour],

$\mathrm{TTR}_{i j}$ : Travel Time by Road transport between city $\mathrm{i}$ and $\mathrm{j}$ [hour],

$\mathrm{TTA}_{i j}$ : Travel Time by Air transport between airport $i$ and $j$ [hour],

To estimate the revenue from the net travel time shortening the value of travel time of departure country [14] and number of passengers [15] has been used Eq [5](6):

$$
V T T S=\sum_{i=1}^{n}\left(T T S_{i j} \cdot \text { pass }_{i j}\right) \cdot V T T_{i}
$$

With the above mentioned process the travel time shortening of air passenger transport compared to road transport has been estimated. The results indicates that more than $45000000000 €$ social revenue has been earned in 2007 by the passenger air transport sector.

\section{Conclusion}

The aim of our article is the investigation of positive effects and revenues of air passenger transport, within this the mathematical modelling of the travel time shortening and estimating its revenue compared to road transport. Instead of the usage of standard 2 norm Euclidean distance the travel time has been applied. Europe's map has been modified by the help of the graph built from the travel time. We demonstrated how the European airports' distance changes if we take the flight time instead of a 
Tab. 3. Net travel time shortening (hour) (source: own research)

Net travel time shortening (hour)

\begin{tabular}{|c|c|c|c|c|c|c|c|c|c|c|}
\hline & Budapest & London & Paris & Vienna & Berlin & Bruxelles & Amsterdam & Madrid & Stockholm & Munich \\
\hline Budapest & 0 & 15 & 12 & 2 & 7 & 10 & 11 & 21 & 18 & \\
\hline London & 15 & 0 & 4 & 13 & 10 & 4 & 6 & 16 & 17 & 10 \\
\hline Paris & 12 & 4 & 0 & 10 & 8 & 2 & 4 & 10 & 16 & 6 \\
\hline Vienna & 2 & 13 & 10 & 0 & 7 & 8 & 7 & 16 & 15 & 3 \\
\hline Berlin & 7 & 10 & 8 & 7 & 0 & 6 & 5 & 19 & 11 & 5 \\
\hline Bruxelles & 10 & 4 & 2 & 8 & 6 & 0 & 1 & 12 & 14 & 6 \\
\hline Amsterdam & 11 & 6 & 4 & 7 & 5 & 1 & 0 & 15 & 13 & 6 \\
\hline Madrid & 21 & 16 & 10 & 16 & 19 & 12 & 15 & 0 & 26 & 16 \\
\hline Stockholm & 18 & 17 & 16 & 15 & 11 & 14 & 13 & 26 & 0 & 15 \\
\hline Munich & 6 & 10 & 6 & 3 & $\underline{5}$ & 6 & 6 & 16 & 15 & 0 \\
\hline
\end{tabular}

geographical distance. We tried to estimate the value of travel time shortening of air passenger transport by the usage of value of travel time of departure country.

\section{References}

1 Kővári B, A közlekedés externáliái, 2008.

2 Markovits-Somogyi R, Török Á., HEATCO kutatási jelentés a Magyarországon végzett zajjal kapcsolatos fizetési hajlandóságról, Vol. 17-18, 2006.

3 US GAO: Aviation and the Environment. Aviation's Effects on the Global Atmosphere Are Potentially Significant and Expected to Grow, 2000, available at wWW.gao.gov/archive/2000/rc00057.pdf GAO/RCED-00-57, United States General Accounting Office: Washington DC.

4 Intergovernmental Panel on Climate Change: Aviation and the Global Atmosphere, Geneva, 1999, available at WwW.grida.no/climate/ipcc/ aviation/index.htm

5 Endres G, World Airlines, Flight International 159 ( 2001), 104-110.

6 Pastowski A, Climate Policy for Civil Aviation: actors, policy instruments and the potential for emissions reductions, Earthscan, London, 2003.

7 Ausubel J H, Marchetti C, Meyer P, Toward Green Mobility: The Evolution of Transport, European Review 6 (1998), 137-156.

8 Bows A, Upham P, Anderson K, Growth Scenarios for EU $\mathcal{F}$ UK Aviation, contradictions with climate policy, Tyndall Centre for Climate Change Research, 2006.

9 Intergovernmental Panel on Climate Change: The Scientific Basis of Climate Change, Cambridge University Press, Cambridge, United Kingdom and New York, NY, USA, 2001, available at WWW.grida.no/climate/ipcc_ tar/wg1/pdf/WG1_TAR-FRONT.PDF Contribution of Working Group I to the Third Assessment Report of the Houghton, J.T., Y. Ding, D.J. Griggs, M. Noguer, P.J. van der Linden, X. Dai, K. Maskell, and C.A. Johnson (eds.).

10 Legeza E, A repülötér és környezetének kapcsolata, Közlekedéstudományi Szemle 7 (2001), 263-268.

11 Airport Council Interntaional: Europe Airport Traffic Statistics, 2007.

12 Giannopoulos G, Aifadopoulou G, Török Á, Port Choice Model for the Transshipment of Containers in Eastern Mediterranean, TRB 87th Annual Meeting, 2008, pp. 25-40. Paper \#08-1517.

13 Szőkefalvi-Nagy B, Valós függvények és függvénysorok, Tankönyvkiadó, Budapest, 1972.

14 Odgaard T, Kelly C, Laird J, HEATCO (Developing Harmonised European Approaches for Transport Costing and Project Assessment) Work Package 3: Current practice in project appraisal in Europe, 2005. SIXTH FRAMEWORK PROGRAMME financed by EU DG-TREN.

15 Directorate-General for Energy and Transport: EU Transport end Energy Figures, 2009, 2008. 